\title{
UPAYA MENINGKATKAN MOTIVASI DAN HASIL BELAJAR FIQIH MELALUI SCIENTIFIC LEARNING DI MAN 1 CILEGON
}

\author{
Oleh. \\ Turiyah \\ Madrasah Aliyah Negeri 1 Kota Cilegon \\ turiyah76@yahoo.com
}

\begin{abstract}
Abstrac
Success in the subject of fiqh is one component that measures the success of the learning process, in addition to achieving academic achievement but has a major influence on the growth and development of student character. So by motivating students is one form of encouragement that comes from outside the individual or from within the individual to influence every activity of students in participating in learning activities. Based on the phenomena that arises there are still many students who follow the lessons have not been effective so that the value obtained is still under standard. This needs an innovation in the form of a learning approach so that classroom learning is not monotonous.
\end{abstract}

\section{Keywords. Effort, motivation, results}

\begin{abstract}
Abstrak
Keberhasilan dalam mata pelajaran fiqih merupakan salah satu komponen yang menjadi tolak ukur keberhasilan dari proses pembelajaran, selain dalam pencapaikan prestasi akademik namun memiliki pengaruh besar dalam tumbuh kembangnya karakter siswa. Maka dengan memotivasi peserta didik adalah salah satu bentuk dorongan yang muncul dari luar individu maupun dari dalam individu untuk mempengaruhi setiap aktivitas peserta didik dalam mengikuti kegiatan pembelajaran. Berdasarkan fenomena yang muncul masih banyak peserta didik yang mengikuti pelajaran belum efektif sehingga nilai yang diperolehpun masih dibwah standar. Hal ini perlu adanya sebuah inovasi berupa pendekatan pembelajaran agar pembelajaran di kelas tidak monoton.
\end{abstract}

Kata kunci. Upaya, motivasi, hasil helajar

\section{A. PENDAHULUAN}

Dalam undang-undang dasar dijelaskan bahwa tiap-tiap warga negara berhak mendapatkan pengajaran. Pemerintah berusaha dan menyelenggarakan satu sistem pengajaran nasional, yang di atur 
dalam undang-undang. ${ }^{1}$ Dalam situasi pembelajaran, guru memiliki peran dan bertanggung jawab atas kepemimpinan yang dilakukannya. ${ }^{2}$ Dalam aktivitas pembelajaran di dalam kelas, tugas guru adalah menjadi pemimpin berlangsungnya kegiatan pembelajaran tersebut.

Setiap guru pada dasarnya telah memiliki gaya, metode, pendekatan dan cara mengajar tersendiri sesuai dengan penguasaanya. Maka hal tersebut sudah barang tentu menjadi ciri khas dan keunikan tersendiri. Selain itu kreatifitas dalam mengembangkan metode mengajar sudah menjadi keharusan bagi setiap guru, karena hal tersebut sangat memiliki hubungan erat dengan ketertarikan siswa terhadap pelajaran yang disampaikan.

Meskipun terkadang masih banyak yang menganggap bahwa peserta didik hanya sebagai botol kosong yang harus diisi ilmu pengetahuan dari gurunya. Padahal keterlibatan siswa dalam kegiatan pembelajaran memiliki pengaruh besar terhadap perkembangan kognitif, afektif dan psikomotoriknya. Sehingga anggapan pada siswa hanya menerima haruslah dirubah bahwa siswa membutuhkan aktivitas dan ikut andil dalam kegiatan pembelajaran.

Dengan demikian menurut ilmu pendidikan Islam, suatu metode yang baik harus memiliki karakter dan

${ }^{1}$ Sardiman, Interaksi dan Motivasi Belajar Mengajar, (Jakarta: PT Raja GrafindoPersada, 2011), hal.171.

${ }^{2}$ Suryosubroto, Proses Belajar Mengajar di Sekolah, (Jakarta: Rineka Cipta, 2009), hal. 3 relevansi yang senada dengan tujuan pendidikan Islam. Ada tiga aspek nilai yang terkandung di dalam tujuan pendidikan Islam, yang hendak direalisasikan melalui metode yang mengandung karakter dan relevansi. Pertama, membentuk peserta didik untuk menjadi hamba Allah yang mengabdi kepada-Nya. Kedua, bernilai edukatif yang mengacu kepada petunjuk Al-Qur'an dan hadis. Ketiga, berkaitan dengan motivasi dan kedisiplinan sesuai ajaran Al-Qur'an dan Hadis.

Dengan mengacu pada arti sebuah pendekatan pembelajaran yang berperan sebagai titik tolak atau sudut pandang terhadap proses pembelajaran yang mengharuskan proses pembelajaran dapat membimbing peserta didik secara aktif untuk mengembangkan potensi dirinya agar memiliki kekuatan spritual keagamaan, kontrol diri (pengendalian diri), dan akhlak mulia (etika) serta keterampilan. $^{3}$ Beberapa pendekatan yang dapat digunakan oleh seorang guru dalam pembelajaran yang mendidik seperti pendekatan individual, pendekatan kelompok, dan lain-lain. $^{4} \quad$ Namun berdasarkan kurikulum 2013, yang sudah mulai berlaku secara bertahap dari tahun 2013 yang lalu menekankan pentingnya pada dimensi pedagogik modern dalam pembelajaran yaitu

\footnotetext{
${ }^{3}$ Dirman dan Cicih Juarsih, Teori Belajar dan Prinsip-Prinsip Pembelajar yang Mendidik, (Jakarta : Rineka Cipta, 2014), hal. 67.

${ }^{4}$ Ibid, hal. 87 .
} 
menggunakan pendekatan Scientific Learning (pembelajaran ilmiah).

Sebagaimana

implementasi kurikulum dalam

Permendikbud No. 65 tahun 2013, berisi tentang standar proses pendekatan Scientific yang di laksanakan dengan langkah-langkah antara lain: mengamati, menanya, mencoba, mengasosiasi, dan mengkomunikasikan untuk semua mata pelajaran. $^{5}$ Ketika sekolah sudah mengikuti kurikulum 2013, maka seorang pendidik juga harus menerapkan sebuah pendekatan yaitu Scientific Learning dalam proses belajar mengajarnya, dan tentu akan menghasilkan pembelajaran dengan baik, serta akan mempengaruhi hasil belajar peserta didik.

Karena pendekatan Scientific Learning ini mempunyai kelebihan antara lain: Proses pembelajaran lebih terpusat pada peserta didik sehingga peserta didik menjadi aktif dan kreatif dalam pembelajaran, dan langkahlangkah pembelajarannya lebih sistematis sehingga memudahkan guru untuk memanajemen pelaksanaan pembelajaran serta diperolehnya hasil belajar peserta didik yang tinggi. ${ }^{6}$

Tetapi yang terjadi di MAN 1 Kota Cilegon, meskipun sebenarnya sudah menggunakan kurikulum 2013 dan sudah menerapkan pendekatan

\footnotetext{
${ }^{5}$ Kementerian Pendidikan dan Kebudayaan RI (2013). Salinan Lampiran Peraturan MenteriPendidikan dan Kebudayaan Republik Indonesia No. 65 tentang Standar Proses PendidikanDasar dan Menengah.

${ }^{6}$ Pendekatan Saintifik, Dalam Kurikulum, and Oleh Bambang Prihadi, (PENERAPAN LANGKAH-LANGKAH PEMBELAJARAN DENGAN', 2014), 1-8.
}

Scientific Learning, hanya saja masih banyak guru yang belum begitu maksimal menerapkan pendekatan Scientific Learning, khususnya pada guru mata Fiqih. Sebab guru masih cenderung atau terbiasa menggunakan metode ceramah atau dikenal dengan chalk and talk, sehingga suasana pembelajaran di kelas tentu tidak akan menjadi kondusif, peserta didik menjadi pasif, kurang aktif, mengantuk, banyak beralasan izin keluar masuk ke kamar mandi, dan bahkan sampai ada beberapa peserta didik yang diam-diam lebih asyik memainkan handphone nya di dalam kelas.

Dalam wawancara dan observasi peneliti bahwa pendekatan Scientific Learning sudah pada dasarnya sudah diterapkan, hanya saja kurang maksimal karena masih banyak siswa mendapatkan nilai dibawah standar berdasarkan pre tes yang peneliti lakukan. Sehingga berdasarkan latar belakang masalah tersebut peneliti berupaya untuk melakukan penelitian tindakan kelas terhadap permasalahan tersebut.

\section{B. METODE PENELITIAN}

Penelitian tindakan kelas ini dilakukan di kelas XI MIPA 4 di MAN 1 Cilegon. Tindakan yang digunakan untuk meningkatkan motivasi peserta didik dan hasil belajar peserta didik dalam bidang studi Fiqih dengan menggunakan pendekatan Scientific Learning. Rencana penelitian tindakan kelas ini dilaksanakan sebanyak 2 siklus, dan berdasarkan refleksi awal tersebut, maka penelitian tindakan 
kelas ini dilaksanakan melalui langkahlangkah sebagai berikut: ${ }^{7}$ planning, acting, observing dan reflecting.

\section{KAJIAN TEORI}

Mc Donald Motivation is a energy change within the person characterized by affecitive arousal and anticipatory goal reactions." Motivasi adalah suatu perubahan energi di dalam pribadi seseorang yang ditandai dengan timbulnya efektif dan reaksi untuk mencapai tujuan. $^{8}$ Menurut Alisuf Sabri motivasi adalah segala sesuatu yang menjadi pendorong tingkah laku atau perbuatan yang menuntut seseorang untuk memenuhi suatu kebutuhan. ${ }^{9}$ Menurut Abraham Maslow motivasi adalah tingkah laku manusia yang dibangkitkan dan diarahkan oleh kebutuhan-kebutuhan tertentu, seperti kebutuhan fisiologis, keamanan, kebutuhan sosial, penghargaan, dan aktualisasi diri. ${ }^{10}$ Dalam konsep Islam peranan motivasi disebut dengan niat dan ibadah. ${ }^{11}$ Niat merupakan pendorong yang paling utama pada

${ }^{7} \mathrm{D} \quad \mathrm{A} \quad \mathrm{N}$ Penguasaan and Konsep Mahasiswa, 'Pembelajaran Pengantar Fisika Kuantum Dengan Memanfaatkan Media Phet Simulation Dan Lkm Melalui Pendekatan Saintifik: Dampak Pada Minat Dan Penguasaan Konsep Mahasiswa', 05.April (2016), 53-60 <https://doi.org/10.24042/jpifalbiruni.v5i1.105 $>$.

8 Oemar Hamalik, Proses Belajar Mengajar, (Jakarta: Bumi Aksara, 2011), hal. 158.

${ }^{9}$ Suparman S, Gaya Mengajar yang Menyenangkan Siswa, (Yogyakarta : Pinus Book Publisher, 2010), hal. 50.

${ }^{10}$ 'Motivasi Belajar Dan Faktor-Faktor Yang Berpengaruh: Sebuah Kajian Pada Interaksi Pembelajaran Mahasiswa Irmalia Susi Anggraini ', 100-109.

${ }^{11}$ Anita Rahmawaty, 'Model Perilaku Penerimaan Internet Banking Di Bank Syari ' Ah : Peran Motivasi Spiritual', 1784-1807. manusia untuk melakukan sesuatu atau beramal, sedangkan ibadah adalah tujuan setiap manusia dalam melakukan sesuatu atau beramal. Kata kunci dalam memaknai motivasi adalah berupa dorongan yang diakibatkan oleh kebutuhan manusia yang dapat berbentuk fisik, psikis bahkan spiritual.

Menurut Darsono, ada beberapa hal yang mempengaruhi motivasi belajar pada peserta didik antara lain: ${ }^{12}$

1. Cita-cita dan aspirasi peserta didik. Cita-cita akan memperkuat motivasi belajar peserta didik baik intrinsik maupun ekstrinsik.

2. Kemampuan peserta didik. Keinginan individual perlu dibarengi dengan kemampuan dan kecakapan dalam pencapaiannya

3. Kondisi peserta didik. Kondisi peserta didik yang meliputi jasmani dan rohani. Seorang peserta didik apabila sedang sakit, maka akan mengganggu perhatian dalam belajar

4. Kondisi lingkungan peserta didik. Kondisi lingkungan peserta didik berupa alam, lingkungan tempat tinggal, pergaulan teman sebaya dan lingkungan sosial atau bermasyarakat ${ }^{13}$

5. Upaya guru dalam membelajarkan pada peserta didik. Guru yang kurang berinteraksi dengan peserta didik secara akrab, menyebabkan proses belajar mengajar itu kurang lancar, peserta didik juga merasa

${ }^{12}$ Lantanida Journal, 'Kedudukan Motivasi Belajar dalam Pembelajaran’, 5.2 (2017).

${ }^{13}$ Kompetensi Dasar, Ayat Jurnal, and Penyesuaian Mata, 'Economic Education Analysis Journal', 1.2 (2012). 
jauh dari guru, maka peserta didik segan untuk berpartisipasi secara aktif dalam belajar. ${ }^{14}$

Pendekatan scientific learning pada umumnya lebih disebut dengan istilah pendekatan ilmiah dan merupakan pendekatan yang diterapkan pada kurikulum 2013. Pada akhir abad ke-19 pertama kali diperkenalkan ke ilmu pendidikan Amerika, sebagai penekanan metode laboratorium formalistic yang mengarah pada faktafakta ilmiah. ${ }^{15} \mathrm{Di}$ dalam kurikulum 2013 yang sudah mulai diterapkan sekarang oleh pemerintah ada yang dikenal dengan istilah pendekatan scientific. Pendekatan scientific learningmerupakan pendekatan yang dilakukan dalam pembelajaran melalui proses ilmiah atau sebuah pendekatan berbasis proses keilmuan. ${ }^{16}$

Pengertian secara istilah, pendekatan scientific learning adalah proses pembelajaran yang sudah dirancang dengan baik agar peserta didik dapat mengonstruksi konsep, hukum atau prinsip melalui tahapantahapan mengamati (observing) yang bertujuan untuk mengidentifikasi masalah atau menemukan masalah, tahap merumuskan masalah, tahap mengajukan atau merumuskan hipotesis, tahap mengumpulkan data

14 Slameto, Belajar dan Faktor-Faktor Yang Mempengaruhi, (Jakarta: Rineka Cipta, 2010), hal. 66.

${ }^{15}$ Imam Ghozali, 'Pendekatan Scientific Learning Dalam', 04.01 (2017), 1-13.

${ }^{16}$ Ghozali. dan tahap menyimpulkan atau mengkomunikasikan. ${ }^{17}$

Pendekatan scientific dapat menggunakan beberapa strategi seperti pembelajaran konstektual. Konstektual berlatar belakang bahwa peserta didik belajar lebih bermakna dengan melalui kegiatan mengalami sendiri dalam lingkungan alamiah, tidak hanya sekedar mengetahui, mengingat, dan memahami. ${ }^{18}$ Dalam pendekatan scientific ini yang dimaksudkan untuk memberi pemahaman kepada peserta didik untuk mengetahui, memahami, mempraktikkan apa yang sedang dipelajari secara ilmiah, oleh karena itu, dalam proses pembelajaran diajarkan agar peserta didik pencari tahu dari berbagai sumber melalui mengamati, menanya, mencoba, mengolah, menyajikan, menyimpulkan dan mencipta dalam semua mata pelajaran. $^{19}$

Komponen-Komponen dalam Pendekatan Scientific Learning yaitu Mengamati (Observing), Menanya (Questioning), Mencoba (Experimenting), Mengasosiasi (Assosiating), Mengkomunikasikan (Communicating)

\section{PEMBAHASAN}

Hasil penelitian ini diuraikan dalam tahapan yang berupa siklussiklus pembelajaran yang dilakukan dalam kegiatan belajar mengajar

${ }^{17}$ Oro-Oro Dowo And Kota Malang, 'Pendekatan Saintifik \& Model Pembelajaran K-13', 5.3 (2016), 116-25.

${ }^{18}$ Musfiqon Dkk, Pendekatan

Pembelajaran Saintifik, (Sidoarjo : Nizamia Learning Center, 2015), hal. 38

${ }^{19}$ Ibid, h. 38 
dikelas. Namun, sebelum peneliti menguraikan hasil penelitian mulai dari siklus I sampai dengan Siklus II, peneliti menguraikan sedikit gambaran tentang hasil observasi pra siklus yang menunjukkan bahwa hasil pembelajaran peserta didik pada nilai Ujian Mid Semester Ganjil pada pelajaran Pendidikan Agama Islam hanya berkisar $32,14 \%$ yaitu terdiri dari 14 peserta didik yang tuntas dari 21 peserta didik. Hal ini menunjukkan bahwa masih rendahnya hasil belajar peserta didik, khususnya kelas XI MIPA 4 di MAN 1 Cilegon pada mata pelajaran Fiqih. Adapun upaya untuk meningkatkan hasil belajar peserta didik yaitu dengan menerapkannya pendekatan pembelajaran Scientific Learning .

Dalam penelitian ini proses pembelajaran dilakukan dengan satu prasiklus dan dua siklus, sebagaimana pemaparannya sebagai berikut ini. Adapun daftar nilai hasil Pre Tes ganjil tahun pelajaran 2018/2019 kelas XI MIPA 4 di MAN 1 Cilegon prasiklus dapat dilihat dalam tabel dibawah ini:

Tabel. 1

Prosentase Ketuntasan Hasil Belajar Peserta Didik Prasiklus

\begin{tabular}{|c|l|c|c|}
\hline NO. & Ketuntasan & Frek & Presentase \\
\hline 1. & Tuntas & 14 & $40 \%$ \\
\hline 2. & Tidak Tuntas & 21 & $60 \%$ \\
\hline \multicolumn{2}{|c|}{ JUMLAH } & 35 & $100 \%$ \\
\hline
\end{tabular}

Dari tabel diatas dapat disimpulkan dengan menerapkan pendekatan scientific learning tetapi masih belum maksimal, dikarenakan Guru masih terbiasa dengan metode ceramah pada waktu prasiklus belum menunjukkan adanya peningkatan karena peserta didik mendapatkan nilai ketuntasan belajar hanya 14 orang sedangkan peserta didik yang belum tuntas sebanyak 21 orang. Jadi, secara klasikal peserta didik belum tuntas dalam belajar.

\section{Siklus I}

Pada siklus I dan II siswa yang mengikuti sejumlah 25 siswa, tiga siswa izin sakit dan tujuh siswa sedang mengikuti pembelajaran di luar sekolah. Maka pada siklus I menunjukkan bahwa proses pembelajaran dengan menerapkan pendekatan Scientific Learning pada materi pernikahan dalam islam, mengalami peningkatan dari hasil belajar sebelumnya yang masih kurang maksimal dalam menerapkan pendekatan Scientific Learning terhadap peserta didik. Dari hasil tes siklus I diketahui bahwa peserta didik yang tuntas dari KKM yang ditentukan 7,5 sebanyak 16 anak (64\%) dari 25 anak dengan nilai tertinggi; 100 dan nilai terendah; 70 dengan nilai rata-rata 82,8 .

Tabel. 2

Prosentase Ketuntasan Hasil Belajar Peserta Didik

\begin{tabular}{|c|l|c|c|}
\hline NO. & \multicolumn{1}{|c|}{ Ketuntasan } & Frek & Presentase \\
\hline 1. & Tuntas & 16 & $64 \%$ \\
\hline 2. & Tidak Tuntas & 9 & $36 \%$ \\
\hline \multicolumn{2}{|c|}{ JUMLAH } & 25 & $100 \%$ \\
\hline
\end{tabular}

Tabel. 3

Prosentase Kategori Motivasi Belajar Peserta Didik Siklus I

\begin{tabular}{|c|c|c|c|}
\hline \multirow{2}{*}{ No. } & \multirow{2}{*}{$\begin{array}{c}\text { Kategori Motivasi Belajar } \\
\text { Peserta Didik }\end{array}$} & \multicolumn{2}{|c|}{ Siklus I } \\
\hline & & Frekuensi & Prosentase \\
\hline 1. & Sangat Aktif & 6 & $24 \%$ \\
\hline 2. & Aktif & 6 & $24 \%$ \\
\hline 3. & Cukup Aktif & 12 & $48 \%$ \\
\hline 4. & Kurang Aktif & 1 & $4 \%$ \\
\hline & Jumlah & 25 & $100 \%$ \\
\hline
\end{tabular}




\section{Siklus II}

Dari data pelaksanaan siklus II menunjukkan bahwa proses pembelajaran dengan menerapkan pendekatan Scientific Learning pada materi wakaf, dasar wakaf, dan prinsipprinsip wakaf, mengalami peningkatan dari hasil belajar sebelumnya. Dari hasil tes siklus II diketahui bahwa peserta didik yang tuntas dari KKM yang ditentukan 7,5 sebanyak 21 anak (84\%) dari 25 anak dengan nilai tertinggi; 100 dan nilai terendah; 70 dengan nilai rata-rata 84,4.

Tabel. 4

Prosentase Ketuntasan Hasil Belajar

\begin{tabular}{|c|c|c|c|}
\hline NO. & Ketuntasan & Frekuensi & Presentase \\
\hline l. & Tuntas & 21 & $84 \%$ \\
\hline $\mathbf{2}$. & Tidak Tuntas & 4 & $16 \%$ \\
\hline \multicolumn{2}{|c|}{ Jml } & $\mathbf{2 5}$ & $\mathbf{1 0 0} \%$ \\
\hline
\end{tabular}

Tabel. 5

Prosentase Kategori Motivasi Belajar Siklus II

\begin{tabular}{|l|l|c|c|}
\hline \multirow{2}{*}{ No. } & Kategori Motivasi & \multicolumn{2}{|c|}{ Siklus II } \\
\cline { 3 - 4 } & Belajar & Frekuensi & Prosentase \\
\hline 1. & Sangat Aktif & 16 & $64 \%$ \\
\hline 2. & Aktif & 8 & $32 \%$ \\
\hline 3. & Cukup Aktif & 1 & $4 \%$ \\
\hline 4. & Kurang Aktif & 0 & $0 \%$ \\
\hline \multicolumn{2}{|c|}{ Jumlah } & $\mathbf{2 5}$ & $\mathbf{1 0 0} \%$ \\
\hline
\end{tabular}

Dari lembar observasi kelompok, dapat dilihat bahwa ada peningkatan dari siklus sebelumnya yaitu peserta didik yang terlibat sangat aktif mencapai 16 orang (64\%) dan peserta didik yang aktif berjumlah 8 orang (32\%) dan sisanya cukup aktif sebanyak 4\%. Hal ini dikarenakan peserta didik sudah mengenal pendekatan Scientific Learning secara maksimal dengan materi dalam Islam.

Penggunaan

pendekatan

Scientific Learning pada materi pernikahan dalam islam dilaksanakan pada pembelajaran di kelas dalam setiap siklus yaitu; siklus I dan siklus
II. Dalam pembelajaran pada materi tersebut dengan menggunakan pendekatan Scientific Learning mengantarkan peserta didik menjadi semakin baik hasil belajarnya karena mudah, menyenangkan, tidak menyulitkan dalam mengikuti pembelajaran dan tidak membosankan bagi peserta didik, sehingga mereka dapat merespon pembelajaran secara mandiri maupun kelompok dengan teman dan Guru secara baik serta dapat memenuhi tujuan pembelajaran yang diinginkan.

Berdasarkan penelitian yang dilakukan di kelas XI MIPA 4, mulai dari prasiklus, siklus I sampai siklus II terdapat peningkatan hasil belajar siswa. Kondisi awal sebelum perbaikan nilai rata-rata mencapai 72,2 , Pada siklus I mulai meningkat memiliki jumlah nilai rata-rata 82,8 lalu pada siklus II meningkat lagi dengan memperoleh jumlah nilai ratarata 84,4, dari skor KKM 7,5, untuk lebih jelasnya dapat dilihat pada tabel berikut:

Tabel. 6

Nilai Rata-Rata pada Prasiklus, Siklus I sampai Siklus II

\begin{tabular}{|l|l|c|}
\hline No. & \multicolumn{1}{|c|}{ Siklus } & Nilai Rata-Rata \\
\hline 1. & Prasiklus & 72,2 \\
\hline 2. & Siklus I & 82,8 \\
\hline 3. & Siklus II & 84,4 \\
\hline
\end{tabular}

Hal ini menunjukkan bahwa dari prasiklus, siklus I sampai siklus II ketuntasan dalam belajar mengalami peningkatan. Dari hasil tersebut dapat disimpulkan bahwa dengan menggunakan pendekatan Scientific Learning dapat meningkatkan hasil belajar siswa pada mata Fiqih. 
Adapun tentang peningkatan motivasi yang dilihat dari aktivitas mereka dalam mengikuti pembelajan di kelas selama dua siklus yang dilakukan oleh peneliti. Untuk lebih jelasnya dapat dilihat pada tabel dibawah ini:

Tabel. 7

\section{Rekapitulasi Persentase Motivasi}

\section{Belajar}

\begin{tabular}{|l|l|c|c|c|c|}
\hline \multirow{2}{*}{ No. } & \multirow{2}{*}{ Kategori Motivasi } & \multicolumn{2}{|c|}{ Siklus I } & \multicolumn{2}{c|}{ Siklus II } \\
\cline { 3 - 6 } & & F & $\%$ & F & \% \\
\hline 1. & Sangat Aktif & 6 & $24 \%$ & 16 & $64 \%$ \\
\hline 2. & Aktif & 6 & $24 \%$ & 8 & $32 \%$ \\
\hline 3. & Cukup Aktif & 12 & $48 \%$ & 1 & $4 \%$ \\
\hline 4. & Kurang Aktif & 1 & $4 \%$ & 0 & $0 \%$ \\
\hline \multicolumn{2}{|c|}{ Jumlah } & $\mathbf{2 5}$ & $\mathbf{1 0 0} \%$ & $\mathbf{2 5}$ & $\mathbf{1 0 0} \%$ \\
\hline
\end{tabular}

Setelah dilakukan analisis terhadap motivasi dan hasil belajar pada siklus pertama dan kedua maka diperloh kesimpulan sementara sebagai berikut:

\section{a. Siklus I}

Dengan menggunakan rumus korelasi product moment dan uji signifikansi di peroleh nilai $\mathrm{t}$ hitung= 1,146 dan $\mathrm{r}$ tabel $=0,396(5 \%)$, sehingga $t$ hitung $>\mathrm{r}$ tabel, maka $\mathrm{H} 0 \mathrm{di}$ tolak. Jadi, ada hubungan yang signifikan antara motivasi dan hasil belajar.

\section{b. Siklus II}

Dengan menggunakan rumus korelasi product moment dan uji signifikansi di peroleh nilai $\mathrm{t}$ hitung $=$ 0,398 dan $\mathrm{r}$ tabel $=0,396(5 \%)$, sehingga $\mathrm{t}$ hitung $>\mathrm{r}$ tabel, maka $\mathrm{HO}$ di tolak. Jadi, ada hubungan yang signifikan antara motivasi dan hasil belajar.

Berdasarkan data dari siklus I dan II, maka dapat disimpulkan bahwa: "Ada pengaruh yang signifikan antara motivasi dan hasil belajar melalui pendekatan Scientific Learning."

$$
\text { Maka dengan demikian }
$$
terjawablah rumusan masalah bahwa pendekatan pembelajaran Scientific Learning dapat meningkatkan hasil belajar dan motivasi peserta didik dalam mengikuti pembelajaran mata pelajaran fiqih.

Jadi, peningkatan nilai atau hasil belajar peserta didik juga sangat dipengaruhi oleh banyaknya tindakan perbaikan yang dilakukan Guru, semakin banyak tindakan perbaikan pembelajaran oleh Guru maupun perbaikan tindakan kegiatan atau aktivitas peserta didik, maka akan semakin baik dalam meningkatkan motivasi dan hasil belajar peserta didik.

\section{E. KESIMPULAN}

Berdasarkan hasil penelitian yang dilakukan di kelas XI MIPA 4 MAN 1 Cilegon tahun pelajaran 2018/2019, maka dapat disimpulkan bahwa penggunaan pendekatan Scientific Learningdapat meningkatkan motivasi dan hasil belajar peserta didik,serta ada pengaruh yang signifikan antara motivasi dan hasil belajar dalam mata Fiqih, dengan taraf signifikansi 5\% atau memperoleh $\mathrm{t}$ hitung=1,146 > $\mathrm{r}$ tabel $=0,396$ dan pada siklus kedua memperoleh $\mathrm{t}$ hitung $=0,398>\mathrm{r}$ tabel $=$ 0,396 . Hal ini bisa dilihat dari hasil peningkatan pada setiap siklus, yakni pada pra siklus memperoleh nilai ratarata 72,2 , selanjutnya siklus I mulai meningkat yakni memperoleh nilai rata-rata sebanyak 82,8 , kemudian meningkat lagi pada siklus II dengan memperoleh nilai rata-rata sebanyak 84,4 . 


\section{DAFTAR PUSTAKA}

Anita Rahmawaty, 'Model Perilaku Penerimaan Internet Banking Di Bank Syari' Ah : Peran Motivasi Spiritual

Dirman dan Cicih Juarsih, Teori Belajar dan Prinsip-Prinsip Pembelajar yang Mendidik, Jakarta : Rineka Cipta, 2014

Imam Ghozali, 'Pendekatan Scientific Learning Dalam, 2017

Kementerian Pendidikan dan Kebudayaan RI (2013). Salinan Lampiran Peraturan MenteriPendidikan dan Kebudayaan Republik Indonesia No. 65 tentang Standar Proses PendidikanDasar dan Menengah. Kompetensi Dasar, Ayat Jurnal, and Penyesuaian Mata, 'Economic Education Analysis Journal, 2012 Lantanida Journal, 'Kedudukan Motivasi Belajar dalam Pembelajaran, 2017

Motivasi Belajar Dan Faktor-Faktor Yang Berpengaruh: Sebuah Kajian Pada Interaksi Pembelajaran Mahasiswa Irmalia Susi Anggraini

Musfiqon Dkk, Pendekatan Pembelajaran Saintifik, Sidoarjo : Nizamia Learning Center, 2015

Oemar Hamalik, Proses Belajar Mengajar, Jakarta: Bumi Aksara, 2011

Oro-Oro Dowo And Kota Malang, 'Pendekatan Saintifik \& Model Pembelajaran K-13, 2016

Pendekatan Saintifik, Dalam Kurikulum, and Oleh Bambang Prihadi, LANGKAH-LANGKAH PEMBELAJARAN DENGAN', 2014

Sardiman, Interaksi dan Motivasi Belajar Mengajar, Jakarta: PT Raja GrafindoPersada, 2011
Slameto, Belajar dan Faktor-Faktor

Yang Mempengaruhi, Jakarta: Rineka Cipta, 2010

Suparman S, Gaya Mengajar yang Menyenangkan Siswa, Yogyakarta : Pinus Book Publisher, 2010

Suryosubroto, Proses Belajar Mengajar di Sekolah, Jakarta: Rineka Cipta, 2009 